\title{
The Analysis of the Frequency of Schmorl's Nodes on the Base of Modic Degeneration as Seen on the Lumbar Magnetic Resonance Imagings of the Cases with Lumbar Pain
}

\author{
Bel Ağrılı Olguların Lomber Manyetik Rezonans Görüntülemelerinde Modik \\ Dejenerasyon Zemininde Schmorl Nodülü Sıklığının İncelenmesi
}

(1) Aysel Gürcan Atçı1 , (1) Ibrahim Burak Atçı²

1istanbul Metin Sabancı Baltalimanı Bone Disease Training and Research Hospital, Clinic of Physical Medicine and Rehabilitation, i̇stanbul, Turkey

2 University of Health Sciences Turkey, İstanbul Training and Research Hospital, Clinic of Neurosurgery, İstanbul, Turkey

\begin{abstract}
Introduction: The aetiology of lumbar pain is multifactorial. One of the primary factors among these is disc degeneration, and degenerative processes lead to endplate changes. This study aimed to determine the incidence rate of Schmorl's nodes (SN), especially those accompanied by modic changes, among cases with lumbar magnetic resonance imaging (MRIs) performed as part of their clinical examination upon arrival at the clinic due to lumbar pain.
\end{abstract}

Methods: This study consisted of 128 patients who were admitted with low back pain and lumbar MRI were taken into the process. Age, gender, pain level has been recorded. All lumbar spinal disc spaces It has been evaluated. The incidence and sizes of the SN reveal SN observed especially with modic degeneration It has been studied in detail.

Results: The cases with and without modic degeneration were evaluated using the significance test for the difference between two proportions, and the results were not statistically significant $(p>0.05)$. The cases with modic type- 1 and type- 2 degenerations were evaluated separately, but the frequency was not statistically significant $(p>0.05)$. The separate comparisons of type- 1 and type- 2 modic degenerations against type-3 resulted in a statistically significant difference $(p<0.05)$.

Conclusion: This study aimed to analyse the prevalence of SN in cases that underwent lumbar MRI due to lumbar pain and to reveal the difference between the frequency, size and pain character of SN in levels with modic degeneration. This study suggests that especially oedematous cases bigger than $10 \mathrm{~mm}$ are triggered by type- 1 and type- 2 degenerations. Analgesic anti-inflammatory treatments can be applied as well as protective treatments and rehabilitative programmes in order to treat these cases. In case of chronic pain, it can be controlled with vertebral fusion, vertebroplasty cement application, bone strengthening and intradiscal operations.

Keywords: Modic degeneration, Schmorl nodule, back pain

\section{öz}

Amaç: Bel ağrısı pek çok etiyolojik faktöre bağlı olarak görülebilir. $\mathrm{Bu}$ faktörlerden öncelikle görülenlerden bir taneside disk dejenerasyonudur. Dejeneratif süreç end plate değişikliklere neden olur. Dejenere endplate Schmorl nodülü (SN) oluşumunu hızlandırabilir. Bu çalıșmamızda bel ağrısı ile polikliniğe başvuran ve lomber manyetik rezonans görüntüleme (MRG) çekilen olgularda SN görülme oranı ve özellikle modik değişiklikle birlikte SN insidansı saptanmaya çalıșılmıștır.

Yöntemler: Son 6 ay içinde bel ağrısı ağrısı ile bașvuran ve lomber MRG çekilen 128 hasta işleme alınmıştır. Olgular yaş, cinsiyet, ağrı düzeyi kayıt altına alınmıştır. Tüm lomber spinal disk aralıkları değerlendirilmiștir. SN görülme sıklığı ve boyutları ortaya konulmuş özellikle modik dejenerasyon ile birlikte gözlenen SN ayrıntılı incelenmiștir.

Bulgular: Modik dejenerasyonlu olan olgularda SN görülme sıklığı, modik dejenerasyon olmadan SN görülme sıklığı arasındaki ilișki istatistiki olarak anlamlı bulunmamıștır $(p>0,05)$. Modik dejenerasyonlu olgularda ise tip-1 dejenerasyon zemininde SN görülme sıklığı tip-2 dejenerasyon zemininde SN görülme sıklığı ile karșılaştırıldığında istatistiksel olarak anlamlı bulunmamıștır $(p>0,05)$. Hem tip-1 dejenerasyon hem tip-2 dejenerasyonuna eșlik eden modik dejenerasyon sıklığı ayrı ayrı tip-3 dejenerasyona eşlik eden modik dejenerasyon sıklığı ile karșılaștırıldığında fark istatistiki olarak anlamlı bulunmuştur $(p<0,05)$.

Sonuç: Çalıșmamızda özellikle bel ağrılı lomber MRG çekilen olgularda SN sıkığını irdelemek ve özellikle de modik dejenerasyon olan seviyelerde SN sıklığı boyutu ve ağrı karakter farklılığını ortaya koymak amaçlanmıștır.Bizim serimizde özellikle çevresinde ödem olan ve çapı $10 \mathrm{~mm}$ daha büyük olguların modik tip-1 ve tip-2 dejenerasyon zemininde olduğunu ortaya koymuștur. Bu olguların tedavilerinde analjezik antienflamatuvar tedaviler yanında tutucu tedaviler rehabilitasyon programları yapılabilmekte olup kronik ağrılarda omurga füzyon cerrahisi, vertebroplasti sement uygulaması ile kemik güçlendirme ve intradiskal girișimlerle ağrı kontrolü sağlanabilir.

Anahtar Kelimeler: Modik dejenerasyon, Schmorl nodülü, bel ağrısı

Address for Correspondence/Yazıșma Adresi: Aysel Gürcan Atçı MD, İstanbul Metin Sabancı Baltalimanı Bone Disease

Training and Research Hospital, Clinic of Physical Medicine and Rehabilitation, İstanbul, Turkey

Phone: +90 5057733155 E-mail: drburakatci@hotmail.com ORCID ID: orcid.org/0000-0001-9490-5406

Received/Geliș Tarihi: 11.05.2020 Accepted/Kabul Tarihi: 15.06.2020

Cite this article as/Atıf: Gürcan Atcı A, Atcı İB. The Analysis of the Frequency of Schmorl's Nodes on the Base of

Modic Degeneration as Seen on the Lumbar Magnetic Resonance Imagings of the Cases with Lumbar Pain.

İstanbul Med J 2020; 21(5): 333-6.

(C) Copyright 2020 by the University of Health Sciences Turkey, Istanbul Training and Research Hospital/istanbul Medical Journal published by Galenos Publishing House.

(C) Telif Hakkı 2020 Sağlık Bilimleri Üniversitesi istanbul Ĕgitim ve Araştırma Hastanesi/Istanbul Tıp Dergisi, Galenos Yayınevi tarafından basılmıștır. 


\section{Introduction}

Lumbar pain is observed frequently among societies. Approximately $84 \%$ of all individuals experience a lumbar pain attack in a period of their lives (1). On the other hand, at least $40 \%$ of individuals were found to incur lumbar pain for 6 months (2). Lumbar pain also has socioeconomic origins. According to a study carried out in the United States, lumbar pain is one of the major reasons for job loss and is responsible for $12.5 \%$ of all losses in labour (3).

The aetiology of lumbar pain is multifactorial. One of the primary factors among these is disc degeneration. Disc degeneration is a progressive process that may arise due to various reasons, and degenerative processes lead to endplate changes. Bone marrow and endplate changes widely observed in spine magnetic resonance imagings (MRIs) were defined by modic. Modic changes are encountered as part of neuroradiologic processes during clinical practices.

On the other hand, Schmorl's nodes (SN) are frequently found in lumbar MRIs. SN were first defined by Christian Georg Schmorl, a German scientist (4). They are expressed as a nucleus pulposus not herniated into the vertebral canal, but into bone. In this respect, vertical disc protrusions are referred to as 'SN' (Figure 1).

This study aimed to determine the incidence rate of SN, especially those accompanied by modic changes, in the cases with lumbar MRIs performed as part of their clinical examination upon their arrival at the clinic due to lumbar pain.

\section{Methods}

This study consisted of 128 patients who were consulted at the University of Health Sciences Turkey, İstanbul Training and Research Hospital Clinic of Neurosurgery within the last 6 months and were diagnosed with lumbar pain. The patients were required have performed lumbar MRIs following their anamnesis and examination results. All the MRIs were conducted with 1.5-T MRI (Siemens Magnetom Symphony, Erlangen, Germany). As a standard practice, T1-weighted spin-echo sequences [510/60/90/2 (TR/TE)] and axial and sagittal T2-weighted turbo spin-echo sequences (3480/102) were obtained. All the MRIs were interpreted by a radiologist.

All the intervertebral disc levels of the patients were assessed separately. The ages, genders and intervertebral disc levels of complaint of the cases were recorded.

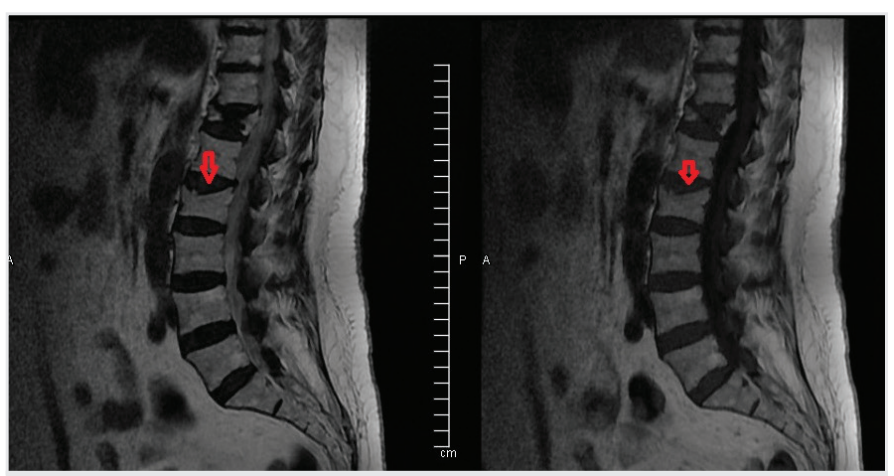

Figure 1. Schmorl nodule
The rates and dimensions of the SN and particularly, the SN with modic degeneration were recorded. Cases with trauma, malignancy, osteoporosis and disc operation history were excluded from the study. The patient's consent was not taken because it was a radiological archive study.

The study protocol was approved by the University of Health Sciences Turkey, İstanbul Training and Research Hospital Ethics Committee (decision number: 2286, date: 10.05.2020).

\section{Statistical Analysis}

Data were analysed using the IBM SPSS for Windows version 23.0 software (IBM Corp. Armonk, NY, USA). Frequency, percentage, mean, standard deviation, minimum and maximum were used for descriptive statistics. The results of the groups were analysed with Mann-Whitney $U$ test. A value of $p<0.05$ was considered statistically significant.

\section{Results}

The participants of this study were selected among the cases who were seen at the University of Health Sciences Turkey, İstanbul Training and Research Hospital Clinic of Neurosurgery between 01.10.2019 and 29.04.2020 due to lumbar pain. After the clinical examination, the patients were asked to do lumbar MRIs. Finally, the patients with SN and particularly, those with concomitant modic degeneration were included in this study. We entered keywords into the radiology archive to retrieve lumbar MRIs and performed the analyses on the images. A total of 128 cases with SN and 768 discs levels were examined, with the inclusion of the thoracolumbar junction. The population consisted of 74 female and 54 male patients. The mean age was $44.11+/-4.7$ with the youngest and oldest patients being 21 and 79, respectively.

Among these, 78 cases (60.9\%) showed millimetric SN in multiple levels, and their sizes varied between 0 and $10 \mathrm{~mm}$. Modic type-1, modic type-2 and modic type-3 SN were found in 20 (15.6\%), 29 (22.6\%) and $1(0.78 \%)$ patients, respectively (Figures $2-4)$. Regarding the cases with modic degeneration, 7 patients showed $10-20 \mathrm{~mm}$ and oedematous SN on modic type-1 degeneration base, while 5 cases showed $10-20 \mathrm{~mm}$ and oedematous SN on modic type-2 base. SN with modic degeneration was observed mostly at L4-5 levels, which corresponded to 21 cases. The second most frequent SN with modic degeneration was at the L5-S1 levels in 11 cases. Similarly, 4 cases with modic degeneration showed SN with the involvement of the L3-4 and L4-5 levels. On the other hand,

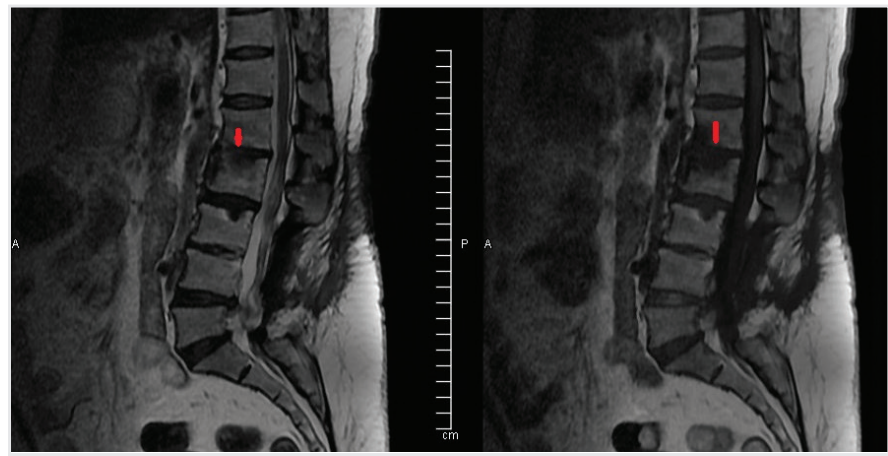

Figure 2. L1-2 Modic type-1 degeneration with Schmorl nodule 
the cases who did not present modic degeneration had SN mostly at the L2-3 and L1-2 levels, respectively.

The cases of SN with and without modic degeneration were evaluated with the significance test for the difference between two proportions, and the results were not statistically significant $(p>0.05)$. The cases of SN with modic type- 1 and type-2 degenerations were evaluated separately, but the frequency did not show statistical significance $(p>0.05)$. The separate comparisons of type- 1 and type- 2 modic degenerations with SN against type-3 modic degeneration with $\mathrm{SN}$ resulted in a statistically significant difference $(p<0.05)$.

\section{Discussion}

Lumbar pain is generally considered as a degenerative disc disease in aetiology. Neuroradiologically, lumbar pain shows a signal intensity with low degenerative disc material in T2-weighted imaging. McGregor was the first person to define degenerative lumbar disc in the aetiology of patients who came to consult due to chronic lumbar pain (5). Endplate changes are frequently observed during the progressive degeneration processes. De Roos et al. (6) defined endplate changes in the lumbar area for the first time in 1987, upon which Modic et al. (7) categorised these endplate changes under three groups. According to the MRIs, T1weighted images demonstrated hypo-intensity in type-1 changes while T2-weighted images showed hyperintensity with fibrovascular tissue in the histopathological section; T1- and T2-weighted images suggested hyperintensity in type- 2 changes with fat in the histopathological section; and T1- and T2-weighted images revealed hypo-intensity in type-3 changes with sclerotic bone in the histopathological section.

The cases with modic type-1 changes were generally defined as acute instability, acute degenerative disease, segmental instability and disc

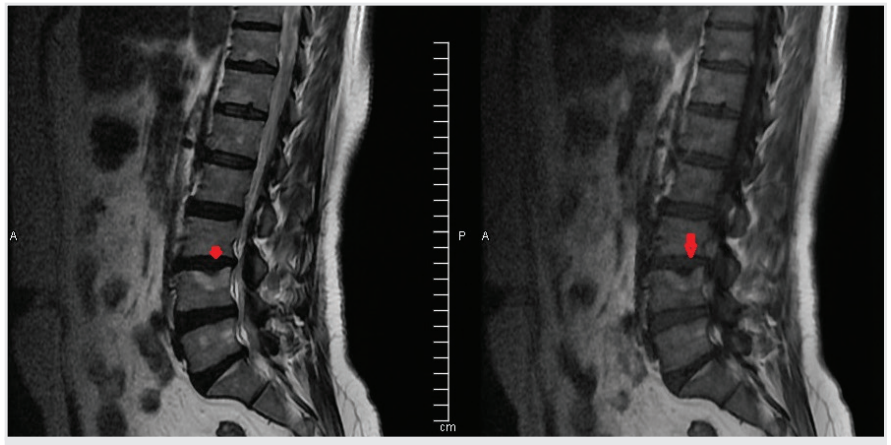

Figure 3. L4-5 Modic type-2 degeneration with Schmorl nodule

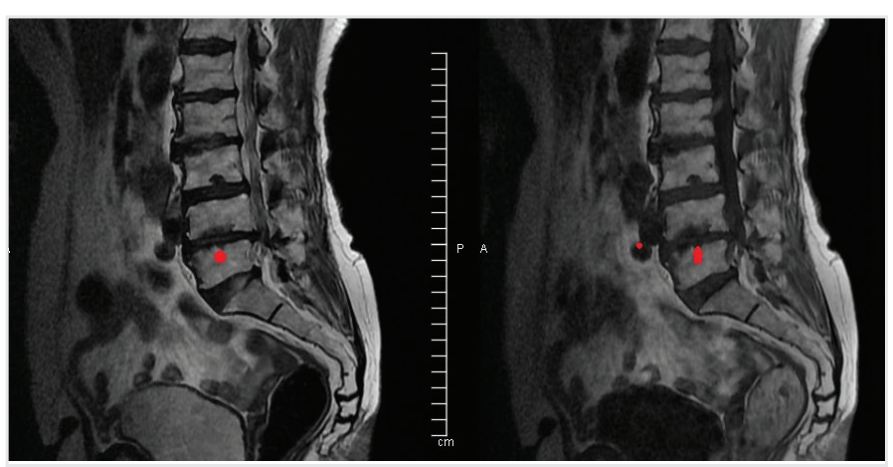

Figure 4. L4-5 Modic type-3 degeneration with Schmorl nodule hernia. The incidence of lumbar pain is observed more in modic type-1 changes. On the other hand, fatty degeneration is present in modic type2 changes, while a great part of these result from the progressive type- 1 cases. Some studies propound that the percentage of symptomatic cases of type-2 is equal to type-1 (8). Type-3 endplate changes are associated with sclerosis. A part of the studies carried out on voluntary patients reported that degenerative endplate changes increased to 10 to $25 \%$ of their population (9).

In 1927, Christian Georg Schmorl, a pathologist, defined a specific lesion in the corpus vertebrae and coined the term SN (10). SN are defined as nucleus pulposus not herniated into the central canal or foramen, but vertically into the bone through the cartilaginous tissue and endplate. They were found to be frequently associated with lumbar pain and following lumbar disc hernia (11). Although trauma, acute or chronic long-term exposition to axial loads, autoimmunity, advanced age, disc degeneration and degenerative bone diseases are alleged to be among the reasons that lead to $\mathrm{SN}$, there is no consensus in the literature regarding its formation $(12,13)$. Its prevalence varies between $38 \%$ and $79 \%$ in cadaver studies (14). In this study, the prevalence of multilevel SN was 51\%. SN below $1 \mathrm{~mm}$ were observed frequently, especially in young adults. In another study, based on the MRIs of 150 maternal and 366 fraternal twins, it was asserted that they may have hereditary origins (15). Cases can show severe pain, but may also be asymptomatic. In this study, most of the cases followed the latter. However, the pain scores increased considerably especially in the $\mathrm{SN}$ cases accompanied by modic type- 1 and type-2 degenerations.

This study aimed to analyse the prevalence of $\mathrm{SN}$ in cases with a lumbar MRI due to lumbar pain and to reveal the difference among the frequency, size and pain character of SN at levels with modic degeneration. The literature suggested that previous studies dwelt on the frequency of SN with lumbar disc degeneration. Disc degeneration increases in frequency with age and is observed in 50\% and $80 \%$ of the population after 40 and 60 , respectively $(16,17)$. Williams et al. (15) reported that there is a correlation between $\mathrm{SN}$ and axial lumbar pain due to disc degeneration. It is also indicated that degenerative disc disease causes rupture in the annulus fibrosis and trigger nucleus pulposus herniation, while endplates decrease axial load resistance due to consequent degeneration. There is no study in the literature to draw attention to the relationship between modic changes and SN. This study suggests that especially oedematous cases bigger than $10 \mathrm{~mm}$ are triggered by type- 1 and type- 2 degenerations (Figure 5), and they show

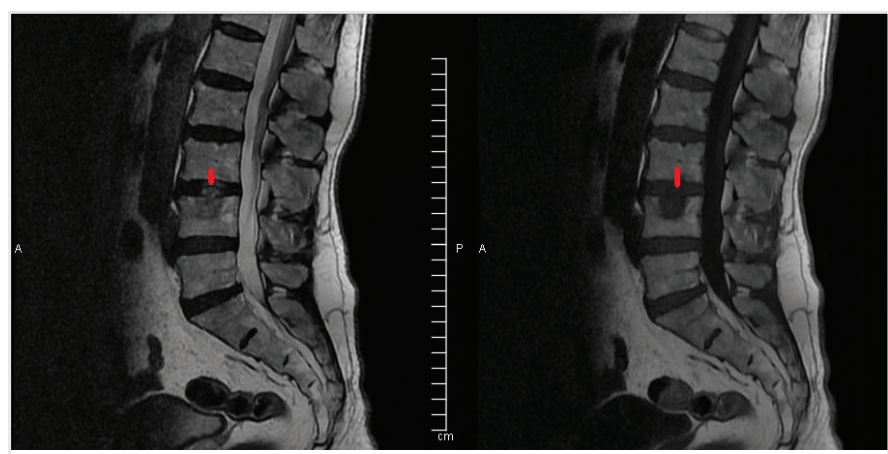

Figure 5. Oedematous case bigger than the $10 \mathrm{~mm}$ Schmorl nodule 
severe pain. Analgesic and anti-inflammatory treatments can be applied as well as protective treatments and rehabilitative programmes in order to treat these cases. In case of chronic pain, it can be controlled with vertebral fusion, vertebroplasty cement application, bone strengthening and intradiscal operations.

\section{Conclusion}

Lumbar pain is frequently observed in clinical practices with lumbar MRIs, as required in many cases. The source of pain can be diagnosed more easily and positive results can be achieved with correct treatment, if T1 and T2 sequence MRIs are carefully examined in middle age or elder cases with lumbar pain, modic changes are thus discovered and particularly, we diagnose SN concomitant with acute oedema as triggered by modic degeneration.

\section{Ethics}

Ethics Committee Approval: The study protocol was approved by the University of Health Sciences Turkey, İstanbul Training and Research Hospital Ethics Committee (decision number: 2286, date: 10.05.2020).

Informed Consent: The patient's consent was not taken because it was a radiological archive study.

Peer-review: Externally peer-reviewed.

Authorship Contributions: Surgical and Medical Practices - A.G.A., I.B.A.; Concept - A.G.A., I.B.A.; Design - A.G.A., I.B.A.; Data Collection or Processing - A.G.A., I.B.A.; Analysis or Interpretation - A.G.A., I.B.A.; Literature Search - A.G.A., I.B.A.; Writing - A.G.A., I.B.A.

Conflict of Interest: No conflict of interest was declared by the authors.

Financial Disclosure: The authors declared that this study received no financial support.

\section{References}

1. Walker BF. The prevalence of low back: a systematic review of the literature from 1966 to 1998. J Spinal Disord 2000; 13: 205-17.

2. Von Korff M, Dvorkin SF, Le Resche L, Kruger A. An epidemiologic comparison of pain complaints. Pain 1988; 32: 173-83.

3. Pittler MH, Karagülle MZ, Karagülle ME, Ernst E. Spa therapy and balneotherapy for treating low back pain. Rheumatology (Oxford) 2006; 45: 880-4.
4. Schmorl G, Junghanns H. The Human Spine in Health and Disease. Besemann EF, translator. 2th ed. New York: Grune and Stratton; 1971.

5. Keyes DC, Compere EL. The normal and pathological physiology of the nucleus pulposus of the intervertebral disc: an anatomical, clinical, and experimental study. J Bone Joint Surg Am 1932; 14: 897-938.

6. de Roos A, Kressel H, Spritzer C, Dalinka M. MR imaging of marrow changes adjacent to end plates in degenerative lumbar disk disease. AJR Am J Roentgenol 1987; 149: 531-4.

7. Modic MT, Masaryk TJ, Ross JS, Carter JR. Imaging of degenerative disk disease. Radiology 1988; 168: 177-86

8. Rahme R, Moussa R. The modic vertebral end plate and marrow changes: Pathologic significance and relation to low back pain and segmental instability of the lumbar spine. AJNR Am J Neuroradiol 2008; 29: 838-42.

9. Chung CB, Vande Berg BC, Tavernier T, Cotton A, Laredo JD, Vallee C, et al. End plate marrow changes in the asymptomatic lumbosacral spine: Frequency, distribution and correlation with age and degenerative changes. Skeletal Radiol 2004; 33: 399-404

10. Schmorl G. Uber die an den wirbelbandscheiben vorkommenden ausdehnungs-und zerreisungsvorgange und die dadurch an ihnen und der wirbelspongiosa hervorgerufenen veranderungen. Verh Dtsch Path Ges 1927; 22: 250 .

11. Coventry MB, Ghormley RK, Kernohan JW. The intervertebral disc: its microscopic anatomy and pathology. Part I. Anatomy, development, and physiology. J Bone Joint Surg Am 1945; 27: 105-12.

12. McGregor AH, Dore CJ, McCharty ID, Hughes SP. Are subjective clinical findings and objective clinical tests related to the motion characteristics of low back pain subjects? J Orthop Sports Phys Ther 1998; 28: 370-7.

13. Fahey V, Opeskin K, Silberstein M, Anderson R, Briggs C. The pathogenesis of Schmorl's nodes in relation to acute trauma. An autopsy study. Spine 1988; 23: $2272-5$

14. Hilton RC, Ball J, Benn RT. Vertebral end-plate lesions (Schmorl's nodes) in the dorsolumbar spine. Ann Rheum Dis 1976; 35: 127-32.

15. Williams FM, Manek NJ, Sambrook PN, Spector TD, Macgregor AJ. Schmorl's nodes: common, highly heritable, and related to lumbar disc disease. Arthritis Rheum 2007; 57: 855-60

16. Lehto IJ, Tertti MO, Komu ME, Paajanen HE, Tuominen J, Kormano MJ. Agerelated MRI changes at $0.1 \mathrm{~T}$ in cervical discs in asymptomatic subjects. Neuroradiology 1994; 36: 49-53.

17. Matsumoto M, Fujimura Y, Suzuki N, Nishi Y, Nakamura M, Yabe Y, et al. MRI of cervical intervertebral discs in asymptomatic subjects. J Bone Joint Surg Br 1998; 80: 19-24. 